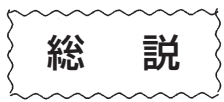

\title{
伝染性膵臓壊死症
}

\author{
佐野元彦 ${ }^{*} \cdot$ 岡本信明
}

（2017年11月 7 日受付）

\section{Infectious Pancreatic Necrosis}

\author{
Motohiko Sano* and Nobuaki Okamoto \\ Tokyo University of Marine Science and Technology, Tokyo 108-8477, Japan
}

(Received November 7, 2017)

\begin{abstract}
Infectious pancreatic necrosis (IPN) was first reported in freshwater trout in 1940's in Canada and in 1950's in the USA, and subsequently spread around the world. The causative agent, infectious pancreatic necrosis virus (IPNV), which was the first fish-virus isolated in a cell culture, is a double-stranded RNA virus in the family Birnaviridae. In 1960's, Japanese rainbow trout aquaculture suffered a lot of fish losses at the fry stage, and the cause was confirmed to be IPNV by the virological study. In 1980's, IPN in Japan has gradually calmed down due to being worked synergistically with hatchery biosecurity practice, increase of host resistance and decrease of virus virulence. However, it is still one of the obstacles in the Atlantic salmon industry in the world.
\end{abstract}

伝染性膵臓壊死症 Infectious pancreatic necrosis（IPN） は, サケ科魚稚魚に膵蔵の壞死などを引き起こすウイル ス感染症である。その原因ウイルス IPNV は魚類ウイル スとして初めて分離され, IPN/IPNV の研究が魚病学, 魚 類ウイルス学, 魚類免疫学を先導してきたと言える。 IPNV と類似したウイルスがブリ，ヒラメ，ウナギなど 100種以上の様々な淡水魚・海水魚から分離されており (Munro and Midtlyng, 2011)，これらのウイルスとIPNV との進化学的な関係は必ずしも明確ではなく, 原因ウイ ルス側から見たときには混乱を生じる。そのため,ここ ではサケ科魚のIPNに限って述べる。

\section{歴史}

膵臓の壊死を特徵とするサケ科稚魚の疾病は, 1940年 代にはじめてカナダのカワマス Salvelinus fontinalis で, 1950年代には米国でもカワマスとニジマス Oncorhynchus mykiss で認められ, 伝染性膵臓壊死症と呼ばれた。その 後, ヨーロッパなど世界中に感染が拡大した。米国東部 魚病研究所の Ken Wolf 博士が原因不明であった本感染症

\footnotetext{
東京海洋大学

* Corresponding author

E-mail: msano00@ kaiyodai.ac.jp
}

病魚から1960年に魚類細胞を用いて原因ウイルス IPNV を分離した (Wolf, 1988)。これが魚類ウイルスの最初の 分離であった。日本では1964年頃から長野県と静岡県の 養殖ニジマス稚魚での不明病として知られるようになっ た。東京水産大学の佐野徳夫博士は, Ken Wolf 博士の研 究室で当時まだ最新の技術であった細胞培養を用いたウ イルス分離・培養を習得し，日本にこの技術を持ち帰り， 病魚からIPNVを分離し，日本で不明病として知られた 疾病がIPNであることをはじめて明らかにした（Sano, 1971)。

ウイルス性の疾病であることが判明し，その後，孵化 施設での隔離飼育, 器具の消毒や操作者の手足の殺菌等 の防除対策の検討が精力的に進められた（「魚類防疫への 挑戦」編集委員会, 2000)。その対策が功を奏し, 日本に おける IPN 発生は1972年頃をピークに減少していき, 1980年代には散発的な発生となった。疾病の原因が明ら かとなり，その対策が講じられるまで, 生残魚を親にし てその子供を採るということが行われたが，これが選抜 育種となったことは想像に難くなく, 実際にニジマス自 体がIPN に強くなっていった（Okamoto et al., 1993）。 原因ウイルスを見ると, 病原性の低い分離株が1980年代 には増加し，このウイルスの弱毒化も加わり，防除対策， 
宿主の抵抗性の増加と相まって, 日本のIPN が減少して いったと考えられている (Okamoto and Sano, 1992)。 日本における IPNV 自体はサケ科魚からしばしば分離さ れるものの, この病勢の弱い状況は今も変わっていない。 一方，ノルウェーなどのタイセイヨウサケ Salmo salar では, 稚魚期からスモルト後の海水馴致時期（海水移行 後 6 ケ月程度）まで発生が見られる他, 感染耐過魚で は膵臓病（alphavirus 感染症）などにも感受性が高く なるなど，IPN は大きな生産障害の一つとなっている (Roberts and Pearson, 2005)。現在，IPNV は北米, ヨーロッパ, 東アジア, 東南アジア, オセアニアなどの 様々な国の天然及び養殖のサケ科魚類で検出される。こ の感染地域の拡大には種卵・種苗の移動および養殖の発 展が密接に関与している。

\section{病原体}

International Committee on Taxonomy of Viruses (ICTV) では IPNV などの 2 本鎖 2 分節の RNA ウイルス を2つ（bi）のRNAの意味でビルナウイルス Birnavirus とし, IPNVをこのビルナウイルス科の Aquabirnavirus 属に分類している。現在，この属には，IPNV，ブリの腹 水症原因ウイルス Yellowtail ascites virus (YTAV), 二枚 貝から分離された Tellina virus（TV-1）の 3 種が記載さ れている。ウイルス粒子は直径約 $60 \mathrm{~nm}$ の球形でエンベ ロープを持たない（Fig. 1)。2 分節のゲノム RNA は分 節 A（約3,100塩基：Accession No. NC 001915） と分節 B（約2,900塩基：NC 001916）と呼ばれ, 分節 A はウイ ルス構造タンパク質のVP2 と VP3 および非構造タンパ ク質の VP4 とVP5 を, 分節 B は RNA 依存 RNA 合成酵 素 VP1 をコードしている。分節 A が病原性や組織親和 性を決定しており (Sano et al., 1992)，さらにウイルス 粒子の表面を構成するカプシドタンパク質 VP2 の特定の アミノ酸部位が宿主特異性, 病原性や血清型と関連して いる（Santi et al., 2004）。Aquabirnavirus の血清型は A,

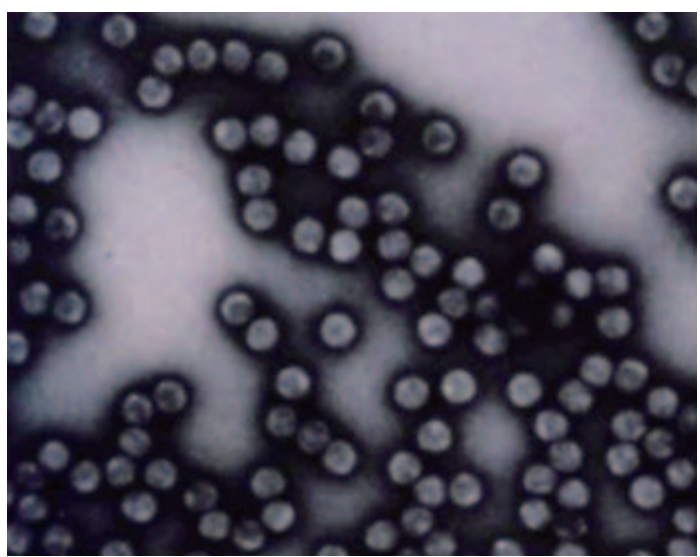

Fig. 1. Negative stained virions of Infectious pancreatic necrosis virus.
$B$ の 2 つに大別され， $A$ 型はさらに $A 1$ A 9 に分けられ る。A1 型にはVR-299, Buhl 株など米国株, A2〜 A5 に はヨーロッパ株 (Sp 株 : A2 型, Ab 株 : A3 型), A6〜 A9 にはカナダ株が主に含まれる。B型には TV-1 が含ま れる（Munro and Midtlyng, 2011）。なお，血清型 Cおよ びDに分類される Blotched snakehead virusなどのビル ナウイルスはICTVの現在の分類ではBlosnavirus 属に分 類されている。インフルエンザウイルスのように分節 RNAの再集合が in vitro に加えて自然界でも起こること が知られ (Sano et al., 1992; Romero-Brey et al., 2009), さらに， 1 粒子中に 2 本以上の RNA 分節がパッケージ されることもあるとされ (Lago et al., 2016), ウイルス が遺伝的に大きな変異を起こす可能性がある。

感染環としては, 稚魚にIPNVが感染し, その生残魚 がキャリアーになり, それから排泄されたウイルスが水 平伝播あるいは卵・精子を介した垂直伝播により次世代 に感染すると考えられる。海産魚から分離される Aquabirnavirusで見れば, 魚の他, 貝や海鳥の粪から検出さ れるなど, 魚, 貝, 鳥を含めた生態系全般で感染環が成 り立っている可能性が高い。

\section{診断 法}

ニジマスでは主に1 g 以下の稚魚が感染し, 食欲が減 退し, きりきり舞するなどの遊泳が見られる。病魚の外 観症状として, 体色黑化, 眼球突出, 腹部膨満, 腹部や 鯺基部の出血などが見られる（Fig. 2)。内部所見として は肝蔵と脾蔵の裉色, 粘液が充満した腸管などが認めら れる。病理組織学的には, 膵臓の腺房細胞およびランゲ ルハンス氏島細胞, また腎蔵, 肝蔵, 脾蔵, 幽門垂と腸 管の粘膜下織などの広範な壊死が認められる（Wolf, 1988）（Fig. 3）。タイセイヨウサケではより大型のスモ ルト後の魚が海水飼育移行後にIPN に罹病し死亡する (Roberts and Pearson, 2005)。

本病の診断は, 病魚からのウイルス分離と特異抗体を 用いた蛍光抗体法や RT-PCR 等の核酸検出法などによる

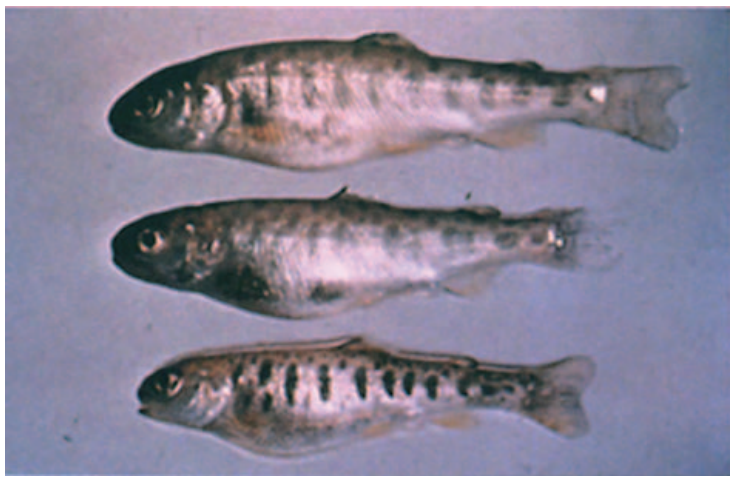

Fig. 2. Infectious pancreatic necrosis in rainbow trout fry displaying darkened body color and abdominal swelling. 


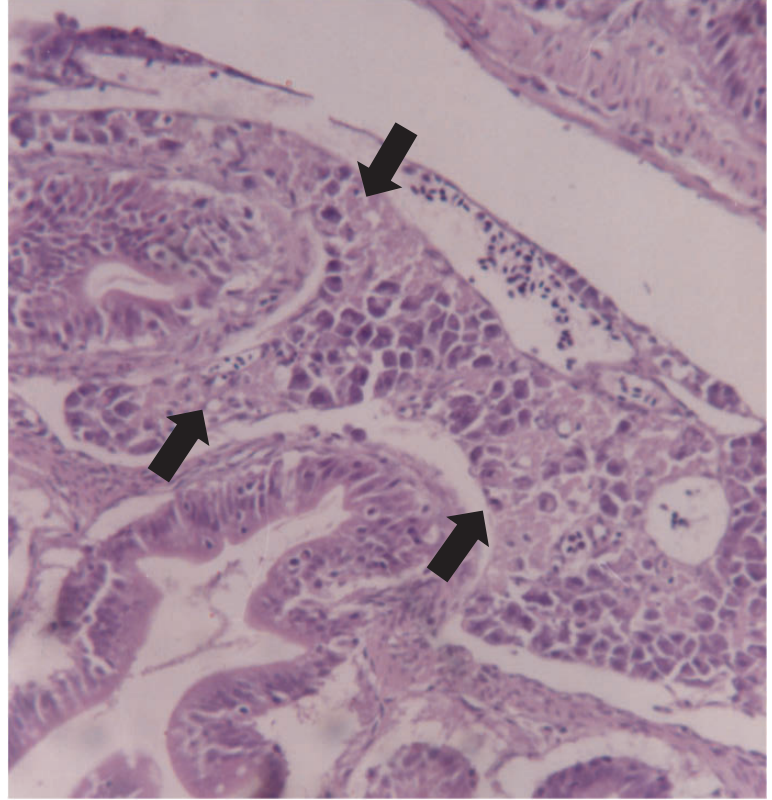

Fig. 3. Severe necrosis of pancreatic acinar cells (arrows) in infectious pancreatic necrosis diseased rainbow trout.

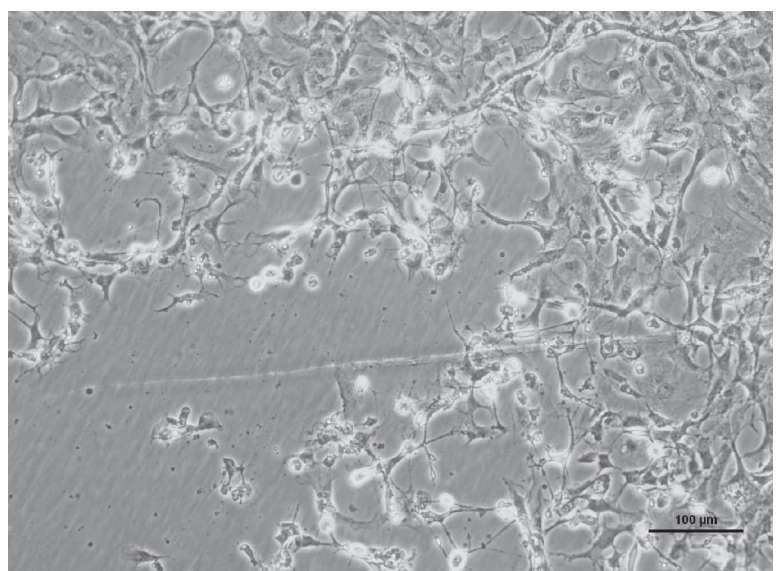

Fig. 4. Cytopathic effect on BF-2 cells following infection with IPNV.

分離ウイルスの同定による。ウイルス分離には，感受性 が高い BF-2細胞のほか，CHSE-214，RTG-2 などのサケ 科魚類由来細胞が用いられる (Fig. 4)。稚魚では個体全 体あるいは内蔵を材料として, より大型のキャリアー魚 検出のための非破壊法では血液, 卵巣液や胸びれのサン プルが用いられる。分離ウイルスの同定法として，中和 試験, 間接蛍光抗体法, ELISA, RT-PCR, 定量 RTPCR, loop-mediated isothermal amplification (LAMP) などが開発されている。ウイルス分離が最も感度と信頼 性が高いが, ウイルス分離は同定まで時間を要すること から，死亡魚などウイルスが多量に存在する材料を用い， 感度を犠牲にしても迅速性が要求されるときには，定量 RT-PCR などを使用する。
対

策

一般的なサケ・マス類での防疫対策が有効である。特 にニジマスでは，ヨード剤で殺菌した受精卵をふ化施設 に搬入し，感受性の高い稚魚時期以降まで隔離飼育する ことは極めて有効である。IPNVが精子に付着して垂直 感染を起こすことが報告されたことがあるが，この実験 の追試は成功して扔らず，実際の養殖で起こるかどうか よく分からない。しかし，受精卵の輸入などの移動によ りIPN が確実に拡がっていった事実もあり，受精卵の受 入れには十分注意し，少なくともヨードによる受精卵の 殺菌と輸送資材の適切な廃棄は欠かせない。

IPNV は塩素, ヨードやオゾンにより不活化される (Munro and Midtlyng, 2011)。エタノールには不活化効果 は無い。紫外線照射も有効であるが，99\%の不活化に 100-150 mJ/cm ${ }^{2}$ の照射が必要とする報告があり，通常 の紫外線照射装置では IPNV の完全な不活化は期待でき ない (Munro and Midtlyng, 2011)。

IPN のワクチンについては，今までに多数の研究があ る (Munang'andu et al., 2014; Dhar et al., 2017)。日本 においては現在のところ IPN の病勢が弱いことからワク チン開発の必要はないが, ノルウェーやチリなどの夕イ セイヨウサケでは種々のワクチンが実用化されている。 不活化ウイルスに加え，免疫原性があるVP2 のサブユ ニットワクチンが主に腹腔内投与（経口投与もある）で 用いられている。ワクチンによる獲得免疫は，中和抗体 を含めた IgM 抗体上昇によるほか, Th1 細胞と細胞障害 性 丁細胞も重要であるとされる。ウイルス侵入門戸にお ける $\lg T$ 抗体の役割はまだ明確ではない (Munang'andu et al., 2014)。また，複数の VP2 から構成されるウイル ス様粒子（VLP）やDNA ワクチンなども研究されてい る。

日本で見出され系統保存されたニジマスのIPN 耐病性 系統と感受性系統を用い，遺伝学的手法で解析する量的 形質遺伝子座 QTLs の探索が魚類の疾病において初めて 試みられた。その結果，IPN 耐病性と連鎖する主遺伝子 座が特定され，マーカーアシスト選抜（MAS）の道が拓 かれた (Ozaki et al., 2001)。タイセイヨウサケにおいて も耐病の選抜育種が行われ，IPN 被害軽減に貢献してい るほか, QTL解析に基づくIPN 耐病遺伝子の特定もなさ れ, epithelial cadherin（cdh1）遺伝子にあることが明ら かにされている (Moen et al., 2015)。

\section{残された課題}

日本においてはサケ・マス類でのIPN 被害はほとんど なく，問題となっていないが，タイセイヨウサケでは海 水馴致期間などで被害があり，世界的に見ると，今後， さらなるワクチン開発が行われ，耐病性に加えて成長， 
肉質などの優良形質を備えた魚の育種は益々研究されて いくものと考えられる。これらを支えるサケ科魚のゲノ ムや遺伝子などの基盤的な知見の集積もさらに必要と考 える。近年, 日本でのニジマス海面養殖が増加してきて おり, タイセイヨウサケでの海水馴致ストレスと IPN 発 生の関係を考えると，海水馴致時期に再びニジマスで IPN が問題となるかもしれず，注視が必要だろう。

サケ科魚以外に由来するIPNV と区別が付かないウイ ルスも知られており，IPNV と類似の Aquabirnavirusの 病原性獲得も含めたウイルスの進化についても明らかに する必要がある。

\section{文献}

Dhar, A. K., S. LaPatra, A. Orry and F. C. T. Allnutt (2017): Infectious pancreatic necrosis virus. In "Fish viruses and bacteria: pathology and protection" (ed. by P. T. K. Woo and R. C. Cipriano). CABI International, Wallingford, pp. 1-12.

「魚類防疫への挑戦」編集委員会 (2000）: 成功 ·失敗事例集 魚類防疫への挑戦（サケ・マス編）。緑書房，東京，187 p.

Lago, M., J. F. Rodríguez, I. Bandín and C. P. Dopazo (2016): Aquabirnavirus polyploidy: A new strategy to modulate virulence?. J.Gen. Virol., 97, 1168-1177.

Moen. T., J. Torgersen, N. Santi, W. S. Davidson, M. Baranski, J. Ødegård, S. Kjøglum, B. Velle, M. Kent, K. P. Lubieniecki, E. Isdal and S. Lien (2015): Epithelial cadherin determines resistance to infectious pancreatic necrosis virus in Atlantic salmon. Genetics, 200, 1313-1326.

Munang'andu, H. M., S. Mutoloki and Ø. Evensen (2014): Acquired immunity and vaccination against infectious pancreatic necrosis virus of salmon. Dev. Comp. Immunol., 43, 184-196.

Munro, E. S. and P. J. Midtlyng (2011): Infectious pancreatic necrosis and associated aquatic birnaviruses. In "Fish diseases and disorders, volume 3: viral, bacterial and fungal infections, 2nd edition" (ed. by P. T. K. Woo and D. W. Bruno). CABI International, Wallingford, pp. 1-65.

Okamoto, N. and T. Sano (1992): Studies on the generation of infectious pancreatic necrosis. In "Salmonid diseases" (ed. by T. Kimura) . Hokkaido University Press, Sapporo, pp. $41-47$.

Okamoto, N., T. Tayama, M. Kawanobe, N. Fujiki, Y. Yasuda and T. Sano (1993): Resistance of a rainbow trout strain to infectious pancreatic necrosis. Aquaculture, 117, 71-76.

Ozaki, A., T. Sakamoto, S. Khoo, K. Nakamura, M. R. Coimbra, T. Akutsu and N. Okamoto (2001): Quantitative trait loci (QTLs) associated with resistance/susceptibility to infectious pancreatic necrosis virus (IPNV) in rainbow trout (Oncorhynchus mykiss). Mol. Genet. Genomics, 265, 23-31.

Roberts, R. J. and M. D. Pearson (2005): Infectious pancreatic necrosis in Atlantic salmon, Salmo salar L. J. Fish Dis., 28, 383-390.

Romero-Brey, I., I. Bandín, J. M. Cutrín, V. N. Vakharia and C. P. Dopazo (2009): Genetic analysis of aquabirnaviruses isolated from wild fish reveals occurrence of natural reassortment of infectious pancreatic necrosis virus. J. Fish Dis., 32, 585-595.

Sano, M., N. Okamoto, H. Fukuda, M. Saneyoshi and T. Sano (1992): Virulence of infectious pancreatic necrosis virus is associated with the larger RNA segment (RNA-segment A). J. Fish Dis., 15, 283-293.

Sano, T. (1971): Studies on viral diseases of Japanese fishes-I. Infectious pancreatic necrosis of rainbow trout: first isolation from epizootics in Japan. Nippon Suisan Gakkaishi, 37, 495-498.

Santi, N., V. N. Vakharia and Ø. Evensen (2004): Identification of putative motifs involved in the virulence of infectious pancreatic necrosis virus. Virology, 25, 31-40.

Wolf, K. (1988): Fish viruses and fish virus diseases. Cornell University Press, New York, 476 p. 